\title{
Governance of Low-Carbon Energy System Transitions
}

\section{A Case Study from North-Rhine Westphalia, Germany}

Philipp Schepelmann ${ }^{\top}$

\section{Introduction}

In his closing address at the 50th Asian Development Bank (ADB) Annual Meeting of the Board of Governors in Yokohama, Japan, on 7 May 2017, ADB President Takehiko Nakao has highlighted "the urgent need to address climate change." This will require considerable investments in Asia. ADB intends to double its annual climate financing to the $\$ 6$ billion by 2020 . Of this, $\$ 4$ billion will be used to support mitigation through investments in sustainable transport, clean energy, and energy efficiency. In his opening address at the 51st ADB Annual Meeting of the Board of Governors in Manila, Philippines, on 5 May 2018, ADB President Takehiko Nakao stated that "approvals for the financing of climate mitigation and adaptation reached a record $\$ 4.5$ billion in 2017, a $21 \%$ increase from the previous year. We are in a good position to achieve our target of doubling annual climate finance to $\$ 6$ billion by 2020 ."

This governance brief aims to provide practical examples on how investments in urban infrastructure, clean energy, and energy efficiency can be implemented; and how these are embedded in multilevel governance, experimentation, and policylearning. In recent literature, targeted governance of structural change is being referred to as transition management (Loorbach 2010, Elzen et al. 2004). This article draws on examples from the German energy system transition (Energiewende), which can be understood as a large-scale, real-life laboratory for the governance of a sustainability transition of an entire national energy system (Schepelmann et al. 2016). In the German federal state of North-Rhine Westphalia (NRW), the climate protection legislation and planning of the government, in combination with key stakeholders in business, civil society, research, and municipalities, have introduced a number of governance and institutional innovations (Lechtenböhmer and Fischedick 2012). The NRW real-life laboratory illustrates the complexity of the governance challenge of implementing low-carbon system transitions.

A senior scientist at the Wuppertal Institute in Germany, who holds a doctoral degree in environmental planning (Dr.-Ing.), and a professorship of political science at the University of Wuppertal. He manages policy analysis and consultancy activities for national and European Union institutions, such as the European Commission, the European Parliament, the European Bank for Reconstruction and Development, and the European Environment Agency as well as nongovernment organizations. 


\section{Green manufacturing and recycling \\ Socioeconomic Background of Climate Protection in North-Rhine Westphalia}

industries in the so-called lead market "resource efficiency" have grown continuously.
In terms of population and gross domestic product, the North-Rhine Westphalian economy is comparable in size to the Australian economy, which also has a strong mining sector but within a much larger territory. NRW extracts 95\% of Germany's hard coal and $53 \%$ of its lignite production. It has an installed power generation capacity of 30,000 megawatts, approximately $77 \%$ of which is based on coal. With annual carbon dioxide $\left(\mathrm{CO}_{2}\right)$ emissions of about 300 million tons (app. 16 tons $\mathrm{CO}_{2}$ per capita), NRW emissions represent about one-third of German greenhouse gas (GHG) emissions.

For an understanding of the German energy system transition (Energiewende), the Ruhr district is of central economic, social, and environmental importance. The Ruhr district comprises 11 cities and 4 counties, and is Germany's largest urban conglomerate. It is named after the river Ruhr that crosses the south of the region from east to west. With a population of 5 million (2015), a local gross domestic product of $€ 154$ billion (2013) (equivalent to $\$ 184$ billion as of 2018), and a labor force of 1.7 million (2016), it is one of Europe's largest industrial clusters.

What is now an urban agglomeration used to be a rural area of small settlements 200 years ago. Having had a population of about 200,000 in the early 19th century, it rose to 4 million before World War I and to 6 million in the 1950s. The massive increase in labor force promoted a rapid increase of the output of coal and steel. During the 1920s-1940s, the output of steel of the Ruhr district exceeded the total steel production of the United Kingdom. In the 1930s, every sixth ton of steel consumed worldwide was produced in the Ruhr district (Schlieper, Reinecke, and Westholt 1986; Kelly and Matos 2010). Steel production peaked in the 1950s, when more than 1 million people were employed in the coal and steel industry. This represented roughly $70 \%$ of the whole labor force of the Ruhr district. The Ruhr industry was Germany's armor factory during both world wars, and helped the country become one of the most industrialized. After World War II, it also provided the natural resources for Germany's rapid economic recovery (Wirtschaftswunder).
The economic decline of the Ruhr district began in the 1960s when world market prices for coal and steel fell below the production costs of the Ruhr industry. New mines in North America and Eastern Europe supplied the markets with cheap coal mined near surface, while the average mining depth in the Ruhr district in 1960 was 650 meters. The demand also began to shift from coal to oil. The results were large-scale closures of factories and mines. Between 1960 and 1990, the Ruhr district lost more than half a million jobs in the rapidly declining coal and steel industry. Even though the massive German economic growth during the 1960 s partly compensated for the job losses, it could not prevent the $15 \%$ unemployment rate in the region in the 1980 , which resulted in a massive emigration of citizens (Reicher 2011).

To mitigate this development, both the state government and the federal government started to support the mining industry with subsidies. Between 1950 and 2008, the German coal industry received a total subsidy of $€ 289$ billion (equivalent to \$335 billion in 2018) (Meyer, Küchler, and Hölzinger 2010). The largest share went to the Ruhr district. Simultaneously, the state started to invest in higher education, by establishing 21 universities. In 2016, 275,000 students had enrolled in these universities.

Based on 50 years of early mover environmental policies and sociopolitical transition (Schepelmann et al. 2016), green markets have matured to a core element of the Ruhr district's economic development strategy. According to the economic development agency of the Ruhr district (Wirtschaftsförderung Metropole Ruhr [WMR] 2016), ${ }^{2}$ green manufacturing and recycling industries in the so-called lead market "resource efficiency" have grown continuously, often more rapidly than the dynamic green industrial sector in the rest of Germany. In 2013, the overall turnover of more than 6,000 companies of this lead market in the Ruhr district amounted to almost $€ 64$ billion (equivalent to $\$ 71$ billion in 2018), which supported about 79,000 jobs.

According to the Green Economy Report of NRW (Ministry for Climate Protection, Environment, Agriculture, Nature and Consumer Protection NRW 2015), green markets have also become a central element of the economic strategy for the rest of NRW. Between 2009 and 2012, the sector grew by $15.6 \%$ (compared to $11.4 \%$ in the rest of Germany). In 2012, around 1,500 patents emerged

2 Economic Development Agency of the Metropolitan Area Ruhr. 
in green sectors with the highest share originating from the Ruhr district. Between 2009 and 2012, exports of NRW's green sector expanded by $26 \%$, reaching a volume of $€ 8.54$ billion (equivalent to app. $\$ 10$ billion as of 2018 ) equivalent to $2.1 \%$ of the global market share. Between 2009 and 2012, employment in the NRW eco-industries increased by $5.4 \%$.

\section{Climate Protection in North-Rhine Westphalia}

The government of NRW's climate protection is based on three pillars:

(i) the Climate Protection Kick-off Program, which was launched in 2011 and has contributed to the implementation of a variety of relevant climate protection measures;

(ii) the Climate Protection Act (CPA), which was adopted by the NRW Parliament in January 2013, setting legally binding targets; and

(iii) the Climate Protection Plan (CPP), which was adopted by the NRW Parliament in December 2015 to specify strategies and actions for shortand long-term sectoral and regional climate protection and adaption.

\section{Climate Protection Kick-off Program}

At the end of 2012, the NRW government launched the Climate Protection Kick-off Program to support core climate change mitigation measures of communities, companies, and private households. The program offers grants and loan schemes. For example, the program has provided $€_{150}$ million (equivalent to $\$ 184$ billion as of 2018 ) annually for energy efficiency in buildings and a total of $€ 250$ million (equivalent to $\$ 290$ billion as of 2018) annually for combined heat and power (CHP) projects. Other measures include a climate change mitigation initiative for communities and an electricity-saving initiative for low-income households.

\section{North-Rhine Westphalia Climate Protection Act}

In June 2011, the state government of NRW decided that, by 2020 , it would reduce its GHG emissions by at least $25 \%$ and, by 2050 , by at least $80 \%$ below the 1990 levels. After the NRW State Parliament (Landtag) passed the Act on the Promotion of Climate Protection in January 2013, for the first time in German history, emissions reduction targets became legally binding. In addition to emission targets, the act also defines adaptation targets.

\section{North-Rhine Westphalia Climate Protection Plan}

To achieve the emissions reduction targets of the CPA, the state government drafted a CPP, which describes strategies and measures to reduce the GHG emission based on three pillars:

(i) resource and energy efficiency,

(ii) energy conservation, and

(iii) renewable energy.

Further, CPP includes climate change adaptation measures.

The CPP aims to support actors in the manufacturing industry, the energy sector, small and medium-sized enterprises, cities and communities, and citizens. Designed as a learning system to be updated in a 5-year planning cycle, the CPP offers grant and loan schemes, funding for research and development, networking opportunities, information, consulting, and educational services.

\section{Participative Governance}

Participative governance is a key component of all three pillars of the transition management. The participation process aims at citizens, research organizations, businesses, and municipalities in the development and promotion of climate protection initiatives and in the integration of expert know-how. Participation aims at increasing ownership among stakeholders, and at shaping new networks and actor coalitions. In cooperation with the Wuppertal Institute, the NRW government has applied innovative participation techniques, including participative scenario-building. These have resulted in a participatory policy design, including (i) the identification of priority areas of action for climate change mitigation and adaptation; (ii) the selection of measures within the prioritized areas of action; and (iii) ex ante impact assessment of specific measures in terms of societal acceptance, employment, cost-benefit ratio, and economic and social viability. For this purpose, the Ministry for Climate Protection, Environment, Agriculture, Nature and Consumer Protection has set up six working groups (energy transformation, manufacturing industry, buildings, transport, agriculture and forestry, and private households), which were supervised and moderated
The NRW

government has

based climate protection on three pillars. 


\section{Participative governance is a key component of all three pillars of the transition management.}

by independent think tanks. Workshops for municipalities, citizens, and businesses were conducted, as well as regional workshops and online surveys. Altogether, the process resulted in the development of 258 measures for climate change mitigation and 100 for adaptation. For example, the working group on construction, manufacturing, trade, and services proposed measures in three priority areas: buildings, cross-sector technologies, and energetic city development. For the building sector, the group identified measures such as efficiency contracting, proactive consultancy services for homeowners, and a study on the potential measure for the modernization of night storage heating.

About two-thirds of the proposed measures were unanimously accepted by stakeholders. In cooperation with stakeholders, scientists conducted impact assessments and developed policy scenarios to allow a transparent assessment of risks and opportunities related to the selected measures and their ability to reduce GHG emissions.

Altogether, the dialogue with government and nongovernment stakeholders, as well as the analysis and processing of results, involved about 12 ministerial staff members and 24 researchers. Drafting the CPP involved more than 400 stakeholders, and is considered the largest participatory, multistakeholder process ever conducted in Germany. After the interministerial consultation, the state government tabled the proposal for the CPP in June 2015. Following a parliamentary debate, the State Parliament (Landtag) approved the CPP in December 2015.

\section{KlimaExpo}

In 2014, the government of NRW launched the initiative KlimaExpo.NRW as an exposition for innovative projects in the areas of climate change mitigation and adaptation. Until 2022, KlimaExpo. NRW will feature different formats of events that highlight the economic opportunities of climate change mitigation and adaptation for NRW, and the state's potential for technological and social innovations in these areas. KlimaExpo.NRW is both a showcase and a laboratory for new ideas and innovation. The initiative will present successful projects to a broad audience to motivate citizens, companies, and cities and communities to play an active role in the low-carbon transition process.

\section{Innovation City Bottrop}

Innovation City aims at the low-carbon transition in urban quarters. ${ }^{3}$ As such, it is an important real-life experiment not only for governance in NRW but also for the German energy transition (Energiewende). In 2010, a regional body consisting of public and private companies (Initiativkreis Ruhr, Box) launched the Innovation City Ruhr competition. Of the 16 participating cities, Bottrop won the award with a participatory blueprint for the governance of an ambitious low-carbon transition process.

Innovation City Bottrop aims at halving $\mathrm{CO}_{2}$ emissions by 2020 (compared to 1990 levels) in an area of 25 square kilometers with 14,500 buildings and 70,000 inhabitants. The targeted area includes several neighborhoods, which represent, in many ways, the cultural and socioeconomic diversity of the Ruhr district. By 2020, the city plans an exemplary application of innovations in energy efficiency, renewable energy generation, decentralized power generation, and electric transport.

Bottrop develops its solutions bottom-up, through collaboration between academia, business, municipal and state administrations, civil society, and the general public. Target groups are, on the one hand, institutions and, on the other, consumers.

\section{Management and Financing}

The Innovation City Management (ICM) is set up as a German limited liability company borne by five public and business shareholders, which support the company with staff, financial resources, and knowhow. As an associated company of the Initiativkreis Ruhr, ICM manages the overall transition process and its almost 300 individual projects. Currently, the core team consists of 25 employees. With an innovative concept for the modernization of parts of the city, Bottrop solves quarter-specific problems and supports municipal utilities, as well as energy suppliers with the development of new sales and business models. The financing of the process is managed in public-private partnership with the European Union (EU) structural funds, regional, municipal, and corporate investments, as well as research and technological development funds.

The operations of the ICM are based on a so-called master plan for the low-carbon city development, which was endorsed by the city

\footnotetext{
3 Bottrop has a population of 117,000. It belongs to the core Ruhr district, and is a typical representative of an old industrial town The population and structure of the city has been shaped by coal mining. It still has the only remaining hard coal mine of the Ruhr district, which will be in operation until 2018.
} 


\section{Box: Roundtable Initiative (Initiativkreis) Ruhr}

As initiator of the Innovation City contest, this roundtable plays a remarkable role in the NorthRhine Westphalia climate protection governance. The roundtable emerged in the late 1980s, after a series of confidential meetings took place at the Catholic diocese of Essen in the Ruhr district. The meetings were attended by eminent stakeholders, including the popular bishop of the Ruhr district, Cardinal Franz Hengsbach, the chief executive officer of Deutsche Bank Alfred Herrhausen, the chair of the energy utility VEBA, the former leader of mining trade union Adolf Schmidt, and the chair of the association pro Ruhrgebiet (a nongovernment organization promoting the transition of the Ruhr district). In 1989, the meetings resulted in the creation of the Initiativkreis Ruhrgebiet as a strong player of the Ruhr district to tackle the multiple structural crisis of the region.

The Initiativkreis Ruhr is chaired by eminent personalities, the so-called "moderators." The first generation of moderators had a background in the energy and steel industries. Recently, the moderators have represented a broader range of sectors. Today, the Initiativkreis Ruhr is an association of around 70 leading companies and institutions of the Ruhr district. Together, the association employs around 2.25 million people worldwide, and generates a global turnover of around $€ 630$ billion (equivalent to $\$ 730$ billion as of 2018). Representatives with a leading function in these companies can become members of the Initiativkreis Ruhr on a personal capacity. The honorary membership is unsalaried and approved by the general assembly. The Corporate Social Responsibility organization is headquartered in the city of Essen. Operations of the association are implemented by the German limited liability company $(\mathrm{GmbH})$, Initiativkreis Ruhr, and other associated companies such as the limited liability company Innovation City Management.

Source: Author.
Innovation City Bottrop develops its solutions bottom-up, through collaboration between academia, business, municipal and state administration, civil society, and the general public. council of Bottrop in April 2014. The 1,300-page master plan proposes the implementation of 350 measures and outlines further steps. This "script" for low-carbon transition considers different technological, social, and economic aspects of implementation and the participation of the citizens of Bottrop.

Two hundred measures of the master plan have already been implemented, or are in the process of being implemented. Measures address sectors such as housing, energy, mobility, infrastructure, and working environment. In the housing sector, activities focus primarily on the energetic refurbishment of homes, including three ambitious demonstration projects, which aim at transforming energy-consuming homes into energy-plus dwellings (which generate, rather than consume, energy). The "CHP 100" creates 100 CHP plants. Current research and development activities aim at integrating the single CHP into a virtual power plant. Other measures include the development of cycle paths and advanced low-carbon mobility concepts. In addition to technological and infrastructure projects, other support actions aim at improving the quality of life, urban gardening, or school education.

Until 2015, the measures and projects had resulted in absolute terms in a reduction of
$\mathrm{CO}_{2}$ emissions of about 100,000 tons, which is equivalent to a $38 \%$ reduction compared to 2010 emission levels. Central to the success of Innovation City is the refurbishment of the building stock. The energy-related modernization in Bottrop is with an annual rate of $3 \%$ - far above the national modernization rate of about $1 \%$. In the pilot area, $16 \%$ of the houseowners have implemented modernization measures of one sort or another.

Key to this remarkable success is a multistage communication approach. All houseowners in the pilot area have access to free low-threshold consulting services. This has led to a combination of more sophisticated support instruments, tailored to serve the specific needs of different target groups. Until March 2016, 2,100 persons had taken advantage of these services. In the target area, about $56 \%$ of the advised persons have actually implemented modernization measures in their dwellings.

The consultancy service is combined with financial support measures of the municipality, which allow direct financial support for energyrelated modernization activities of building owners. Depending on the type of building and the potential for $\mathrm{CO}_{2}$ reductions, a financial support of up to $25 \%$ can be realized. 
The improvement

of stakeholder

participation in

climate change

mitigation can also

accommodate other

ADB priorities.
Between April 2014 and September 2015, 111 individuals had applied for a total financial support of $€ 3.58$ million (equivalent to $\$ 4.1$ million as of 2018). The city has already accepted grants with a total volume of another $€_{382,000}$ (equivalent to $\$ 441,000$ in 2018) has already been invested. This is equivalent to an average support quota of almost $15 \%$.

\section{Impacts on the Private Sector and Employment} Innovation City Bottrop addresses three ADB priority areas:

(i) creation of quality jobs,

(ii) promotion of private sector development, and

(iii) combatting climate change.

Together, all government and nongovernment stakeholders have invested $€ 183$ million (equivalent to $\$ 211$ million in 2018) in low-carbon transition. Until 2020, another more than $€ 290$ million will be invested (equivalent to app. \$335 million as of 2018). About $€ 110$ million (equivalent to $\$ 127$ million in 2018) has been invested in the private sector, while $€ 26$ million (equivalent to $\$ 30$ million in 2018) has been invested in services and consumption.

During the total transition period, the employment increase will amount to 924 personyears. The indirect employment effects will result in 276 person-years. Thus, Innovation City Bottrop will result in additional employment totaling 1,200 person-years, which is equivalent to about 300 jobs.

\section{Innovation City Rollout}

Before its end in 2020, Innovation City Bottrop will have been a success story, attracting interest among many national and international stakeholders of the global low-carbon transition. Therefore, the regional government of NRW has decided to finance a diffusion process, involving other 20 urban quarters, the so-called Innovation City Rollout drawing on the EU structural funds.

During a 3-month preparatory phase, a jury has selected 20 urban quarters. They have been chosen to be representative for the Ruhr district related to aspects such as urban development, consumption and production patterns, and demography.

In July 2016, the conceptualization phase has begun to lay the conceptual basis for the reduction of $\mathrm{CO}_{2}$ emissions in urban quarters. The conceptualization for each quarter will be implemented in close cooperation with municipalities. Depending on the urban target area, it will most likely take 6 months. The quarter concepts are based on different modules: in addition to the analysis of basic characteristics, planners developed the energetic refurbishment and energy supply concepts. In parallel, the rollout is prepared with a concept for communication and activation of stakeholders.

The conceptualization phase ends with contracts between stakeholders in the quarters, aiming at implementing the conceptualized measures in the framework of an integrated quarter development. This will eventually lead to the implementation phase.

\section{Roundtable Ruhr}

The rollout aims to initiate the transition toward low-carbon development trajectories in 20 selected urban quarters. In addition, it lays the foundation for monitoring real-life laboratories to enable policy-learning and adaptive governance. Therefore, a broad regional knowledge transfer and diffusion process is integrated into the rollout. All relevant stakeholders of the region and the city quarters will meet at regular roundtables to exchange information on failures, experiences, and best practice. The roundtables will also invite interested stakeholders from other municipalities of the Ruhr district, government, and nongovernment organizations, academia, as well as expert institutions and funding agencies. The process is open to interested stakeholders from outside NRW.

\section{Summary and Conclusions}

In his opening remarks at the Civil Society Program of the 5oth ADB Annual Meeting of the Board of Governors, ADB Vice-President Bambang Susantono stressed: "An effective partnership between governments, civil society, private sector, and donors is at the heart of Strategy 2030." The evidence presented in this policy paper supports the argument for cooperative governance. Furthermore, it indicates that the improvement of stakeholder participation in climate change mitigation can also accommodate other ADB priorities, such as the promotion of private sector development and the creation of quality jobs.

The energy system transition in the state of NRW is embedded in the global multilevel governance framework of climate policy. An ambitious legal framework of the state (CPA) frames a multistakeholder implementation plan (CPP), which is financially and logistically supported 
with a public support program (Climate Protection Kick-off Program) in combination with research, development, demonstration, and diffusion of social and technological innovations (KlimaExpo, Innovation City).

\section{Stakeholder Participation is Key in Moderating Role} Participatory governance is a key component of the NRW transition management. The participation of citizens, researchers, businesses, and municipalities in the development and promotion of climate protection policies increases ownership among stakeholders and shapes new networks and actor coalitions. The stakeholder participation in the NRW climate protection planning involved more than 400 stakeholders and resulted in the development of 258 measures for climate change mitigation and 100 for adaptation. About twothirds of the proposed measures were unanimously accepted by stakeholders.

The decision and act of the elected government and local parliament defined the objectives of the NRW climate policy as contribution to the German and EU climate policy. This mandated the state administration to frame a participatory process. In this process, the government plays more of a moderating role, supported by research, feeding in evidence, including modelling and scenario-building.

\section{Experimentation, Learning,} and Good Practice Diffusion

To motivate stakeholders to play an active role in the low-carbon transition process, the government supports innovation with showcase and demonstration activities, such as the KlimaExpo or the Innovation City Bottrop. This article has highlighted some of the most noteworthy aspects of the Innovation City project.

The energy sector is currently undergoing rapid structural change and adaptation in response to the turnaround in German energy policies (Energiewende). Remarkably, carbon-intensive industries have initiated and contributed to the ambitious low-carbon development project of the innovation cities. Originally launched with a competition by an exclusive institutional hybrid of industrialists and public institutions (Initiativkreis Ruhr), Innovation City Bottrop has become an innovative public-private partnership for climate change mitigation and adaptation, and the improvement of living conditions. It has set ambitious goals for the low-carbon transition of an entire city and implements the transition with a mix of research, development, and demonstration of technological and social innovations.

From a governance perspective Innovation City has some remarkable features, such as the initiation by industry actors as well as the public-private partnership in implementation and financing. Based on careful comparative policy analysis, opportunities and limitations of adopting similar structures and intermediary agents in the Asian context could be further explored. Systems transitions have to take into account the complex interdependencies of modern societies, touching sensitive interests of strategic sectors (energy, mobility, and housing). The energy sector has never been a market free from public interventions. It is deeply connected to social, economic, and geostrategic stakes. There is no universal policy mix for climate change policies. Therefore, energy system transition strategies have to be tailored to the particular cultural, political, and socioeconomic realities of societies. In the absence of ubiquitously applicable governance approaches, real-life experimentation has strong potential for finding sustainable solutions.

An experimental approach of monitoring large real-life laboratories, such as Innovation City Bottrop or the large low-carbon urban development schemes of the People's Republic of China, shows great potential. The urgency of climate change mitigation and adaptation requires more rapid policy-learning, more effective diffusion mechanisms of best practice, and improved adaptive management. $A D B$, in coordination with other like-minded multilateral development banks, could play a central role in facilitating such a muchneeded global mutual learning process. This policy paper may be seen as a modest contribution to such an exchange of experience.

The governance brief was peer reviewed by Ramola Naik Singru, senior urban development specialist, Urban Development and Water Division, ADB; and Srinivasan Ancha, principal climate change specialist, Environment, Natural Resources and Agriculture Division, $A D B$.
The government plays more of a moderating role, supported by research, feeding in evidence, including modelling and scenario-building. 
An experimental

approach of

monitoring large

real-life laboratories

shows great potential.

\section{References}

Elzen, B., F. W. Geels, and K. Green, eds. 2004. System Innovation and the Transition to Sustainability: Theory, Evidence and Policy. Cheltenham: Edward Elgar Publishing.

Fischedick, M. 2015. The participatory process to a low-carbon economy in the German state of NRW. Energie, Ambiente e Innovazione. Speciale: Transition and global challenges towards low carbon societies, DOI: 10.12910/EAI2015-016

Kelly, Thomas D. and Grecia R. Matos. 2010. Historical statistics for mineral and material commodities in the United States", in: U.S. Geological Survey Data Series 140; at: <http://pubs. usgs.gov/ds/2005/140/> (accessed December 2016).

Lechtenböhmer, Stefan and Manfred Fischedick. 2012. Smart City - Schritte auf dem Weg zu einer $\mathrm{CO}_{2}$-armen Stadt. In Schneidewind, Uwe; Servatius, Hans-Gerd; Rohlfing, Dirk (Eds), Smart Energy: Wandel zu einem nach haltigen Energiesystem. Heidelberg: Springer: pp. 395-414.

Loorbach, Derk. 2010. Transition management for sustainable development: a prescriptive, complexity-based governance framework. Governance, 23(1), pp. 161-183.

Meyer, Bettina, Swantje Küchler, and Oliver Hölzinger. 2010. Staatliche Förderungen der Stein-und Braunkohle im Zeitraum 1950-2010. FÖS-study commissioned by Greenpeace; at: <https://www.greenpeace.de/files/ Kohlesubventionen_1950-2008_o.pdf> (accessed December 2016).

Ministry for Climate Protection, Environment, Agriculture, Nature and Consumer Protection, North-Rhine Westphalia (NRW). 2015. Green Economy Report North Rhine-Westphalia 2015. Düsseldorf: MKULNV NRW

Reicher, Christa, Klaus R. Kunzmann, Jan Polívka, Frank Roost, Yasmine Utku, and
Michael Wegener (eds). 2011. Schichten einer Region - Kartenstücke zur räumlichen Struktur des Ruhrgebietes. Berlin: Jovis.

Schepelmann, Philipp. 2006. Euro-Asian environmental cooperation - a European perspective. In Paul Welfens et al. (eds). Integration in Asia and Europe: Historical Dynamics, Political Issues and Economic Perspective. Heidelberg: Springer, pp. 169-178.

Schepelmann, Philipp, René Kemp and Uwe Schneidewind. 2016. The eco-restructuring of the Ruhr district as an example of a managed transition. In Hans Günter Brauch, Úrsula Oswald Spring, John Grin, Jürgen Scheffran (eds.). Handbook on Sustainability Transition and Sustainable Peace. Hexagon Series on Human and Environmental Security and Peace 10. Heidelberg, New York, Dordrecht, London: Springer-Verlag. ISBN: 9783-319-43882-5 (Print) - ISBN: 978-3-319-43884-9 (Online) - DOI 10.1007/978-3-319-43884-9.

Schlieper, Andreas, Heike Reinecke, and HansJoachim Westholt. 1986. 150 Jahre Ruhrgebiet: ein Kapitel deutscher Wirtschaftsgeschichte. Düsseldorf: Schwann.

Wirtschaftsförderung Metropole Ruhr, ed. 2016. Wirtschaftsbericht Ruhr 2015. Essen: Wirtschaftsförderung Metropole Ruhr. https://www.adb.org/terms-use\#openaccess

ISBN 978-92-9261-230-6 (print), 978-92-9261-231-3 (electronic)

ISSN 2520-6591 (print), 2520-6605 (electronic

Publication Stock No. BRF189406 http://www.adb.org/publications/corrigenda

pubsmarketing@adb.org

https://www.adb.org/publications/series/governance-briefs

DOI: http://dx.doi.org/10.22617/BRF189406 